\title{
CONIFER - Connecting Finnish-Russian Forest Sector Expertise
}

\section{Timo Leinonen ${ }^{1 *}$ and Anu Honkanen ${ }^{2}$}

1 Finnish Forest Research Institute, P.O. Box 68, FI-80101 Joensuu, Finland; E-Mail: timo.leinonen@metla.fi

2 Lappeenranta University of Technology, Northern Dimension Research Centre NORDI, P.O. Box 20, Skinnarilankatu 34, FI-53851 Lappeenranta, Finland; E-Mail: anu.honkanen@lut.fi

* Author to whom correspondence should be addressed; E-Mail: timo.leinonen@ metla.fi; Tel.: +358 29532 2320; Fax: +358295323113.

Received: 6 July 2013/ Accepted: 15 July 2013 / Published: 17 July 2013

\begin{abstract}
The forest industry in Finland and Russia are currently facing great challenges due to an economic downturn in both countries' main market in Europe, a decrease in demand and prices of paper, and increasing production costs and taxes. New ways and approaches should be found to support the competitiveness of the forest sectors in Finland and Russia, especially in Northwest Russia. An innovative idea to establish a Finnish-Russian Forest Academy was created in the project "Finnish-Russian Forest Academy Preparation" (4/2011-3/2013) and in its continuation project (12/2012-11/2014) funded by South-East Finland-Russia ENPI CBC programme. The main activities of the latter two-year project are 1) finalizing the establishing of Finnish-Russian forest expertise center 2) education and training planning and marketing, and piloting professional training courses and 3) research incubation; preparing a plan for prioritized research and survey projects and conducting first joint research activity on recent changes in the business environment of the Russian forest sector. The Academy was decided to rename as CONIFER with a slogan "Connecting Finnish-Russian Forest Sector Expertise". In the starting phase CONIFER will operate as an open network connecting experts and professionals from different fields of the forest sector. All interested parties are welcome to become members of CONIFER and develop joint events and projects in education, research and business development.
\end{abstract}

Keywords: forest education and training; forest industry; forest policy; forest research; investments; trade of forest industry products 


\section{Introduction}

The forest sector cooperation between Finland and Russia has been very active during the last 20 years. In the field of research, education and development, the flagship of the cooperation was the Finnish-Russian Development Programme for Sustainable Forest Management and Conservation of Biological Diversity in Northwest Russia (NWRDP) [1]. This programme was implemented in four phases in 1997-2011 in the framework of the neighbouring area cooperation coordinated in Finland by the Ministry for Foreign Affairs. In NWRDP I-IV, over 30 joint projects were realized, covering a wide range of topics from seed production to wood transportation, from forest planning to research in forest product markets. More than 500 Russian directors, experts, and lecturers were trained and a total of 200 experts from both countries participated in the project implementation [2].

As in 2011 the Government of Finland decided to reform neighbouring area cooperation with Russia and to reduce appropriations used for it, new ways for the forest sector cooperation were needed [3]. An innovative idea to establish a Finnish-Russian Forest Academy was created in a project called "Finnish-Russian Forest Academy Preparation" funded by the South-East FinlandRussia ENPI CBC programme on 4/2011-3/2013. The aim was to establish a Finnish-Russian network or organization to promote cooperation in the forest sector between Finland and Russia. During the project, the needs and wishes of regarding Finnish-Russian forest sector cooperation were surveyed with a questionnaire and interviews in different companies and organizations in Finland and Russia [4]. According to the survey, Finnish respondents saw the most promising topics for future cooperation sustainable use of forest resources and biodiversity, facilitating the imports/exports of round wood, and the modernization of the Russian forest sector. Russian respondents, representing largely educational establishments, answered joint projects in education (professional training in particular), research field and sustainable use of forest resources to be most important topics to cooperate.

Although needs and support for cross-border cooperation were quite different in Finland and Russia according to the respondents, support and coordination was expected on both sides of the border. The respondents of the survey were almost $100 \%$ favour to found the Finnish-Russian Forest Academy indicating that there is a need for an independent organization/network/actor that would connect experts and expertise, backup organizations in their business activities or collaboration in Russia, provide information, organize training events, bring together research ideas and researchers, facilitate implementation of research results into the business.

\section{What is CONIFER?}

On the basis of positive feedback from the respondents of inquiry and interviewed experts and from the financing body, a second phase of the project called "Finnish-Russian Forest Academy 2 Extension and Piloting" was launched in December 2012 for 24 months [5]. The aim of the project is to establish the Finnish-Russian coordination center of joint activities in education, research and business development in forestry and forest related industries, and with the aim of piloting joint 
activities in education and research. The main activities of the two-year project are 1) finalizing the establishment of Finnish-Russian forest expertise center, incl. concept, structure, functions, management and financing 2) education and training planning and marketing, and piloting professional training courses and 3) research incubation; preparing a plan for prioritized research and survey projects and conducting a first joint research activity on "Recent changes in business environment of Russian forest sector: impacts of Russian forest law and forest strategy on investment climate" [6,7]. Tools and methods anticipating future changes will be utilized as well as SWOT-analysis, semi-structured interviews, and cost-benefit analyses, used also in earlier studies $[8,9]$. As in the preparatory project, the project partners are the Lappeenranta University of Technology (lead partner), St. Petersburg State Technological University of Plant Polymers, St. Petersburg State Forest Technical University with associate partners the Committee of Natural Resources of Leningrad Region and VIPKLH - All-Russian Institute of Continuous Education in Forestry (Pushkino, Moscow region). A new partner - Finnish Forest Research Institute Metla came in on the second phase of the project.

The Steering Group of the project decided in its first meeting to rename the Academy as "CONIFER" with a slogan "Connecting Finnish-Russian Forest Sector Expertise". Moreover, the Steering Group decided that CONIFER will at least in the starting phase operate as an open network. When the current ENPI project comes to its end, the questions of the legal structure, coordinating body and financing have to be solved.

\section{What CONIFER can do?}

The role of CONIFER in the cross-border cooperation is seen as

- Organizing seminars, events, courses and discussion forums

- Coordinating education and training, research \& development projects

- Creating new R\&D partnership for cross-border cooperation and regional development

- Initiating joint $\mathrm{R} \& \mathrm{D}$ projects, collaboration between authorities and cooperation which generates knowledge, business and trade

- Linking experts and expertise, educational, research institutions and forest-related industries

On the basis of the questionnaire study and interviews among different forest sector organizations in Finland and Russia, proposed CONIFER's activities and themes of cooperation are diverse and give a good base for planning of concrete joint activities (Fig. 1.) 


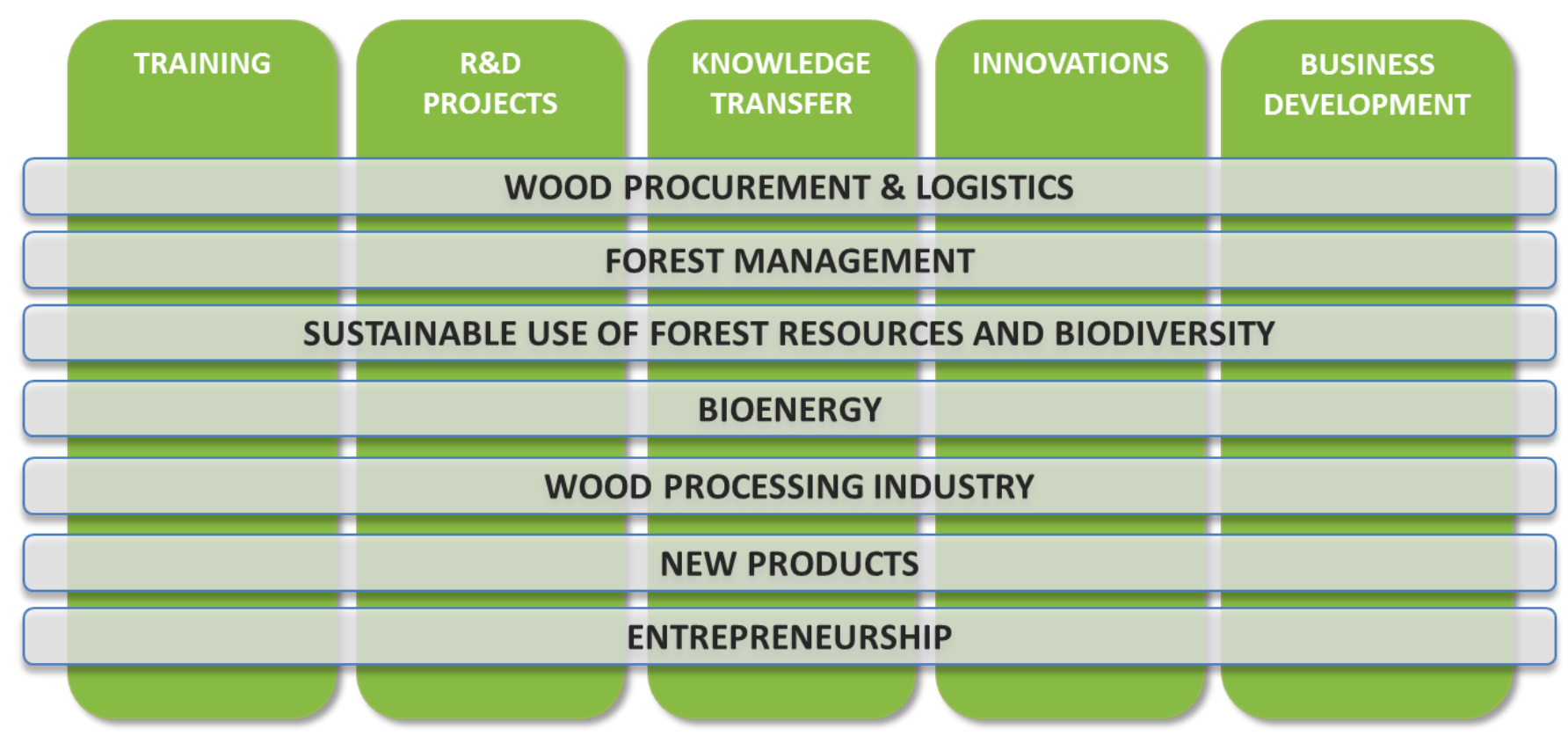

Figure 1. Preliminary activities and topics of cooperation within CONIFER.

\section{Discussion and Conclusions}

CONIFER is a promising initiative to connect experts and professionals from different fields of the forest sector from Finland and Russia to implement joint activities in the field of education, research and business development. The forest industries in Finland and Russia are currently facing great challenges due to an economic downturn in both countries' main market in Europe and a decrease in demand and prices of paper, and increasing production costs and taxes $[10,11,12]$. Relevant and concrete joint actions should be implemented more than today in order to strengthen the competitiveness of our forest sectors and assist the conservation and development of forestry and the forest industry in the boreal forest zone. CONIFER is an excellent forum for this kind of joint activities. All interested parties are invited to become members of CONIFER and together build more competitive forest sectors in both countries!

\section{Acknowledgments}

This work has been carried out under the project "Finnish-Russian Forest Academy 2 - Extension and Piloting" funded by the South-East Finland-Russia ENPI CBC Programme 2007-2013.

\section{References}

1. Bilateral forestry cooperation with 2013. http://www.mmm.fi/en/index/frontpage/forests/eu_international_cooperation/bilateral/russia.ht ml. [Cited 4 July 2013]. 
2. Leinonen, T. 2010. Cooperation between Finland and Russia in forest sector: past, present, and future (in Russian). Sustainable Forestry 24 (2): 2-7.

3. Anon. 2011 a. Programme of Prime Minister Jyrki Katainen's Government. Retrieved from: http://valtioneuvosto.fi/hallitus/hallitusohjelma/pdf/en334743.pdf. [Cited 4 July 2013].

4. Anon. 2012. Report on industry round in Finland and Russia. Finnish-Russian Forest Academy preparation project. Report 05/2012, 25 pp.

5. Finnish-Russian Forest Academy 2013. Retrieved from: http://www.lut.fi/web/en/nordi/finnishrussian-forest-academy. [Cited 4 July 2013].

6. Anon. 2006. Forest Code of the Russian Federation. No. 200-FZ. Retrieved from: http://faolex.fao.org. [Cited 4 July 2013].

7. Anon. 2013. Draft Resolution of the Government of the Russian Federation "On approval of the basis of the state policy in the field of use, protection and regeneration of forests in the Russian Federation for the period up to 2030" Retrieved from: http://www.mnr.gov.ru/online/detail.php?ID=130957. [Cited 4 July 2013].

8. Toppinen, A., Toivonen, R., Mutanen, A., Goltsev, V. \& Tatti, N. 2007. Sources of competitive advantage in woodworking firms of Northwest Russia. International Journal of Emerging Markets 2: 383-394.

9. Bouriaud, L., Kastenholz, E., Fodrek, L., Karaszewski, Z., Mederski, P., Rimmler, T., Rummukainen, A., Sadauskiene, L., Salka, J. \& Teder, M. 2011. Policy and market-related factors for innovation in forest operations enterprises. In Innovation in Forestry - Territorial and Value Chain Relationships, Weiss, G., Pettenella, D., Ollonqvist, P., Slee, B. (Eds.), CAB International, Wallingford, UK, pp. 276-293.

10. Hänninen, R., Sevola, Y. (Eds.) 2012. Finnish Forest Sector Economic Outlook 2012-2013. Finnish Forest Research Institute, Helsinki, Finland, 38 pp.

11. WhatWood.ru. 2012. Russian forest industry in 2012 (In Russian). Whatwood.ru, Moscow, Russia, 83 pp.

12. FAO 2012. The Russian Federation Forest Sector Outlook Study to 2030. FAO, Rome, Italy, $93 \mathrm{pp}$.

(C) 2013 Leinonen, T., Honkanen, A. 